\title{
Frequency of risk infections for congenital infection in pregnant women
}

\section{Frecuencia de infecciones de riesgo para infección congénita en mujeres embarazadas}

\author{
Heriberto Caballero-Ortega, ${ }^{1^{*}}$ Luz Belinda Ortiz-Alegría, ${ }^{2 *}$ Ana Laura Castañeda-Huitrón, ${ }^{3}$ Chiharu Murata, ${ }^{4}$ \\ Ricardo Figueroa-Damián, ${ }^{5}$ María Dolores Correa-Beltrán ${ }^{6}$
}

\begin{abstract}
BACKGROUND: TORCH and other infections can be vertically transmitted and provoke abortions or result in congenitally infected newborns. Most babies are born with subclinical infection but have a high risk of developing sequalae later.

OBJECTIVE: To determine the frequency of seven endemic infections that represent risk for vertical transmission among pregnant women of a tertiary care hospital.

MATERIALS AND METHODS: Prospective, cross-sectional study carried out in pregnant women attended at the INPer between 2010 and 2012. Infections were investigated by serological risk markers among pregnant women living in the Valley of Mexico and answered a questionnaire including risk factors.

RESULTS: A total of 1079 pregnant women were studied, and the overall frequency of infection was $5.7 \%$. Anti-Toxoplasma gondii low avidity $\operatorname{lgG}(2.0 \%)$ and parvovirus B19 IgM (2.0\%) were the most common. No HBV S-Ag and one rubella case were detected. An association of markers studied with fetal malformations and transfusions $(\mathrm{p}<0.015)$ was found. Toxoplasma infection was associated with the last two variables, as well as with the consumption of raw meat, previous positive TORCH and infection with HPV. Parvovirus B19 IgM was associated with stillbirths, and T. pallidum with HIV. Four cases had double infections.

CONCLUSIONS: This study supports the success of vaccination control programs against rubella and active $\mathrm{HBV}$, although infections or perinatal risk are still challenging for this group of women and their children's health.

KEYWORDS: Abortions; Congenitally; Newborns; Subclinical infection; Vertical trans-
\end{abstract} mission; Pregnant women; México; Toxoplasma gondii.

Resumen

ANTECEDENTES: Las infecciones del síndrome TORCH, y otras, pueden trasmitirse verticalmente, provocar abortos o dar lugar a recién nacidos infectados congénitamente. La mayoría de los recién nacidos nacen con alguna infección subclínica, lo que los coloca en un riesgo alto posterior de secuelas.

OBJETIVO: Determinar la frecuencia de siete infecciones endémicas que representan un riesgo de trasmisión vertical en las mujeres embarazadas atendidas en un hospital de tercer nivel.

MATERIALES Y MÉTODOS: Estudio prospectivo y transversal efectuado en mujeres embarazadas atendidas en el INPer entre los años 2010 a 2012. Las infecciones se determinaron con marcadores de riesgo serológico en mujeres embarazadas habitantes del Valle de México y que respondieron un cuestionario que incluía factores de riesgo. RESULTADOS: Se estudiaron 1079 mujeres embarazadas en quienes resultó una frecuencia global de infección del 5.7\%. Los anticuerpos lgG de avidez baja anti-Toxoplasma gondii $(2.0 \%)$ y los IgM contra parvovirus B19 (2.0\%) fueron los más frecuentes. Solo se detectó un caso de rubéola y ninguno de antígeno de superficie de hepatitis B. Se encontró una asociación con los marcadores estudiados con malformaciones fetales
${ }^{1}$ Investigador en Ciencias Médicas, Laboratorio de Inmunología Experimental. http://orcid.org/0000-0003-4269-8251 ${ }^{2}$ Investigadora en Ciencias Médicas. Laboratorio de Inmunología Experimental. http://orcid.org/0000-0002-0681-780X

${ }^{3}$ Laboratorio de Inmunología Experimental.

${ }^{4}$ Investigador en Ciencias Médicas, Departamento de Metodología de la Investigación.

${ }^{5}$ Servicio de Infectología. Instituto Nacional de Perinatología Isidro Espinosa de los Reyes (INPer), Ciudad de México.

${ }^{6}$ Investigadora en Ciencias Médicas. Laboratorio de Inmunología Experimental. http://orcid.org/0000-00023354-4421.

* Ambos autores comparten la primera autoría.

Instituto Nacional de Pediatría, Ciudad de México.

Received: August 11, 2020

Accepted: February 18, 2021

Correspondence

María Dolores Correa-Beltrán

mariadol@yahoo.com

This article should be cited as: $\mathrm{Ca}$ ballero-Ortega H, Ortiz-Alegría LB, Castañeda-Huitrón AL, Murata Ch, Figueroa-Damián R, Correa-Beltrán MD. Frequency of risk infections for congenital infection in pregnant women. Acta Pediatr Méx 2021; 42 (3): 102-11. 


\begin{abstract}
y transfusiones $(\mathrm{p}<0.015)$. La infección por T. gondii se asoció con estas dos últimas variables y con el consumo de carne cruda, TORCH previo positivo e infección por el virus del papiloma humano. La IgM contra parvovirus B19 se asoció con mortinatos y T. pallidum con VIH. Cuatro casos tuvieron infecciones dobles.

CONCLUSIONES: Este estudio sustenta el éxito de los programas de control de vacunación contra la rubéola y la hepatitis $\mathrm{B}$, aunque las infecciones o el riesgo perinatal siguen siendo un desafío para este grupo de mujeres y para la salud de los niños.

PALABRAS CLAVE: Abortos; congénito; recién nacido; infección subclínica; trasmisión vertical; mujer embarazada; México; Toxoplasma gondii.
\end{abstract}

\section{BACKGROUND}

Infectious diseases that affect humans during the antenatal period are public health problems. Toxoplasma gondii, Treponema pallidum, varicella-zoster, parvovirus B19, rubella, cytomegalovirus (CMV), herpesvirus, human immunodeficiency virus (HIV) and other infections can be vertically transmitted and produce spontaneous abortions or congenitally infected newborns, most of whom are born without apparent problems, but having a high risk of developing sequelae later in life. ${ }^{1,2}$ Congenital infections occur most often in developing countries, being CMV the most common worldwide. ${ }^{2,3,4}$ Other congenital infections, including those caused by human papillomavirus (HPV), HIV, rubella or hepatitis B and C (HBV and HCV, respectively), are less frequent among newborns, but they are mostly severe. ${ }^{2,5}$ For infections such as toxoplasmosis and parvovirus B19, the actual frequency and risk are unknown in many parts of the world.

In some nations, prevention programs for congenital infection include education and the diffusion of healthy practices, prenatal and postnatal screening, and when it is useful, prophylactic treatment. ${ }^{3,6}$ Likewise, there are eradication or control programs based on vaccination against some of these infectious agents, including rubella and HBV. ${ }^{7,8}$ Conversely, some diseases, such as syphilis, are emerging or re-emerging; therefore, their frequency is unfortunately increasing. ${ }^{3}$ In Mexico, there are few reports on the frequency of these infections in pregnant women, particularly regarding coinfections and associated risk factors. However, the limited data available indicate that they are present and at a relatively high frequency. ${ }^{9-15}$

The aim of this study was: To determine the frequency of seven endemic infections that represent risk for vertical transmission among pregnant women of a tertiary care hospital of Mexico City.

\section{MATERIAL AND METHODS}

Ethics approval: This project was reviewed and approved by the Research and Ethics Committees of the Instituto Nacional de Perinatología (INPer; reg. number: 212250-02231) and the Instituto Nacional de Pediatría (INPed; reg. number: 002/2008. IRB-NIH numbers IRB00008064 and IRB00008065).

Enrolled patients: The INPer is a tertiary care hospital for women with high-risk pregnancies. The hospital has 100 beds and a mean of 3,000 to 4,000 births per year. Pregnant women who came to INPer and agreed to participate in the study were included and the corresponding informed consent was obtained for each one. Prenatal screening was performed in 1,079 women from the central zone of Mexico, i.e., Ciudad de México, Estado de México, Hidalgo, Morelos, Puebla, Querétaro and Tlaxcala. Approximately 98\% of the samples came from Ciudad de México and Estado de México and these states comprise most of the megalopolis of the Valley of Mexico; although it is a spatially small region, it covers about $20 \%$ of the total population of the country. Because the purpose of the project was to screen acute infection markers and to test the risk status of vertical transmission in a cross- 
sectional study, only first-contact patients were included. Subsequently, those who were positive to any marker were referred to their group of physicians for diagnosis confirmation, monitoring and medical control. They were stratified by age into five groups. Due to ethical and management reasons, most women screened were in the first $(18.1 \%)$ and second (81.6\%) trimester of gestation. Blood samples were taken along two years (November 2010 to November 2012).

Serologic markers for seven infections were assessed. The women also answered a questionnaire, which included exposition-related factors and clinical manifestations; it also contained a question about any other infection they wanted to inform such as HIV; some women stated history of HPV infection, because they had genital warts (condyloma acuminatum). Figure $\mathbf{1}$ shows the flow chart of the study strategy.

\section{Serologic tests}

We searched for markers considered as potential risk for vertical transmission. ${ }^{16,17}$ Specifically, for
CMV, rubella, T. pallidum, and parvovirus B19 IgM class antibodies were determined using commercial enzyme-linked immunosorbent assays (ELISAs) as follow: CMV (VIDAS CMV IgM), rubella (VIDAS RUB IgM), T. pallidum (VIROTROL Syphilis Total and BioPlex ${ }^{\circledR} 2200$ Syphilis IgM kit from Bio-Rad, California, USA), and parvovirus B19 (LIAISON ${ }^{\circledR}$ Biotrin Parvovirus B19 IgM kit from DiaSorin, Saluggia, Italy). HBV (Santigen) and HCV (total antibodies) were tested by commercial kits from BioMerieux (Marcy I'Etoile, France). The manufacturers' instructions were followed to perform these procedures. Unfortunately, 249 serum samples could not be tested for syphilis or T. gondii, due to cold storage problems. Since specific $\lg M$ is not of value for acute toxoplasmosis diagnosis, we searched low IgG avidity antibodies against T. gondii, by means of a homemade ELISA. ${ }^{18}$

The association between the variables that the women declared in the questionnaire and the serological markers was determined (referred from here on as "risky infection") by odds ratio with 95\% confidence intervals using the $\chi^{2}$ or Fisher's

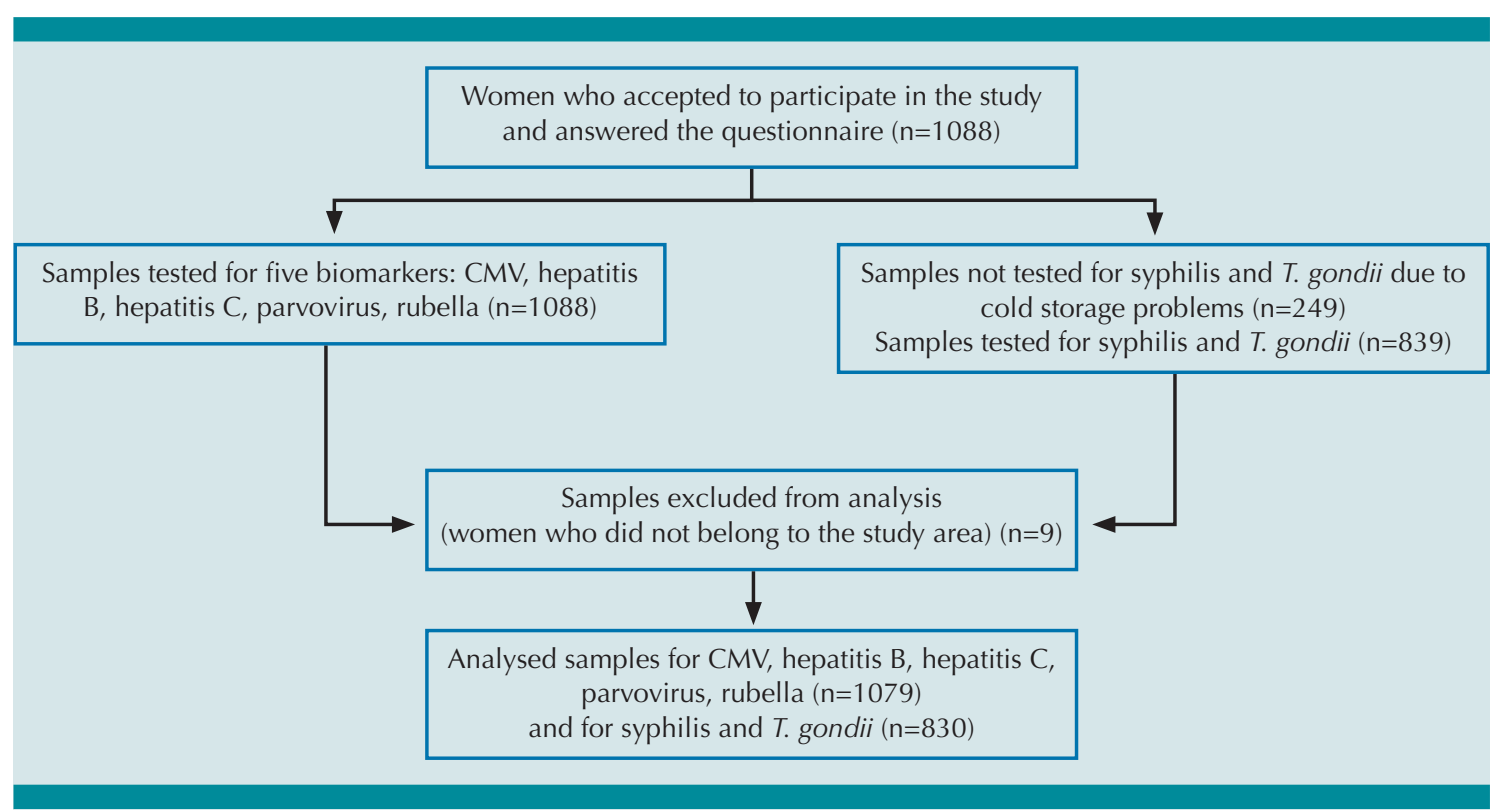

Figure 1. Flow chart showing the enrollment process of pregnant women as well as the final number of samples tested for seven biomarkers of acute infection. 
exact tests to assess statistical significance. A p value $\leq 0.05$ was considered significant.

\section{RESULTS}

A total of 1,079 pregnant women who lived in the urban area of the Valley of Mexico were screened for perinatal infections. The women ranged from 13 to 46 years of age, with peaks at 16 and 36 years (Figure 2). Most women enrolled (93.6\%) had between one and four pregnancies, including current, while 69/1079 women reported having between five and up to eight pregnancies. Fifty-two $(4.8 \%)$ women reported at least one multiple pregnancy; these were more frequent among women with one to four gestations than in those who had five or more (5.0 vs $2.9 \%$ ). The univariate analysis based on the questionnaire rendered the following results: most women ate outside of their homes and had dogs as pets; and one-third had chronic illnesses, mainly non-immunological and non-infectious, including hypothyroidism, hypersensitivity and hypertension. Urinary tract infections and cervicovaginitis were the most frequent gynecological problems (67.0 and $53.8 \%$, respectively). Fifty three percent of the women had been subjected to surgery before the survey. Few patients reported the consumption of non-intravenous drugs or infectious diseases, such as tuberculosis. Table 1

The global proportion of the risky infections was $5.7 \%$, which ranged from 0 for $\mathrm{HBV}$ to $2.0 \%$

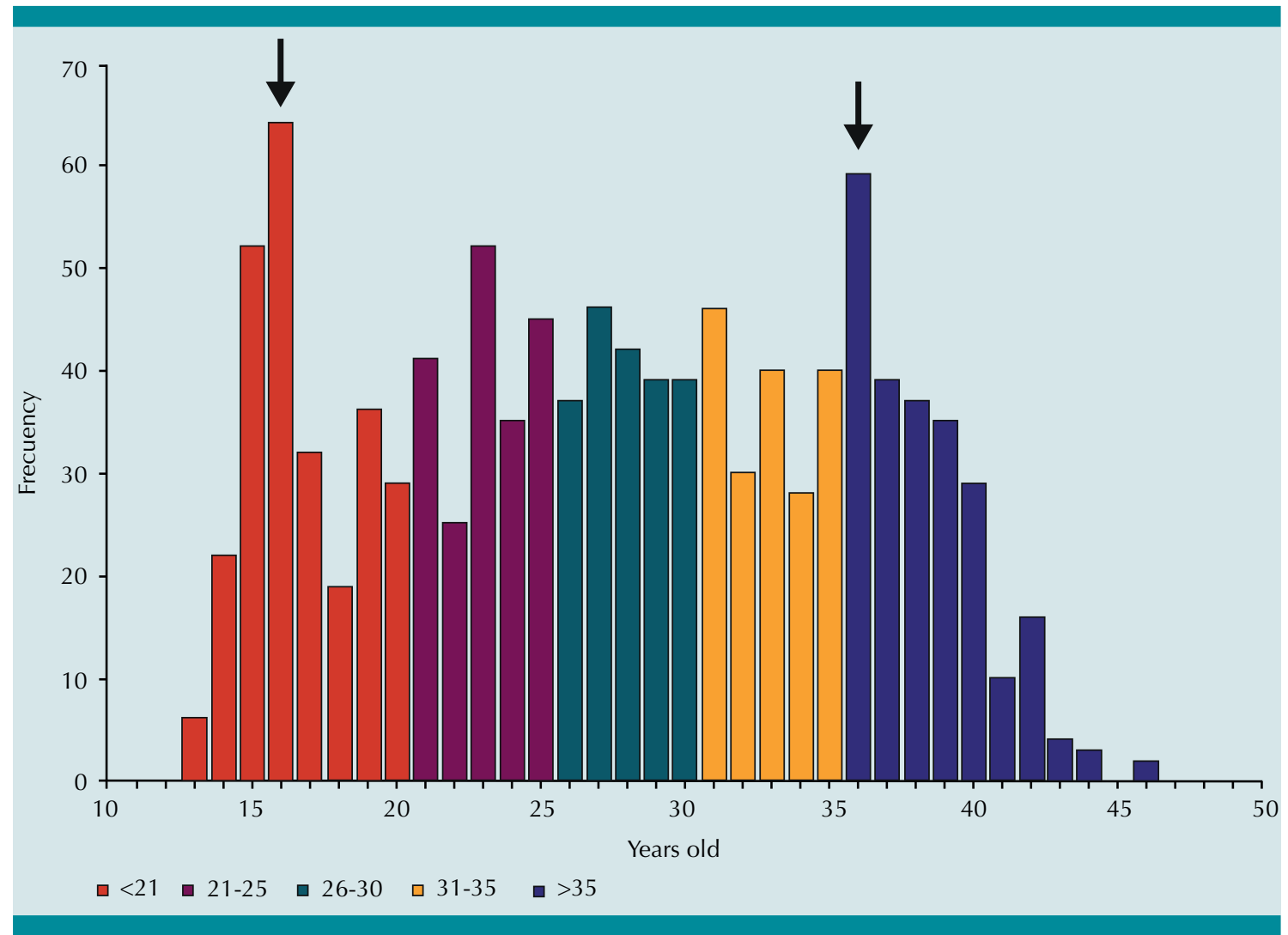

Figure 2. Age range of women studied, stratified into five groups; with peaks at 16 and 36 years are marked with black arrows. 
for parvovirus B19 and T. gondii (Table 2). The frequency of risky infection markers increased with age, reaching a peak at 26 years and older. Syphilis was detected in two women and rubella in one. Four women had double co-infections, being parvovirus B19 the most frequent agent (two with CMV and one with HCV), in addition a case of co-infection of T. pallidum and T. gondii was found.

Statistically significant associations of several aspects asked in the questionnaire and

Table 1. Epidemiological, clinical and background characteristics among 1079 pregnant women from a tertiary care hospital

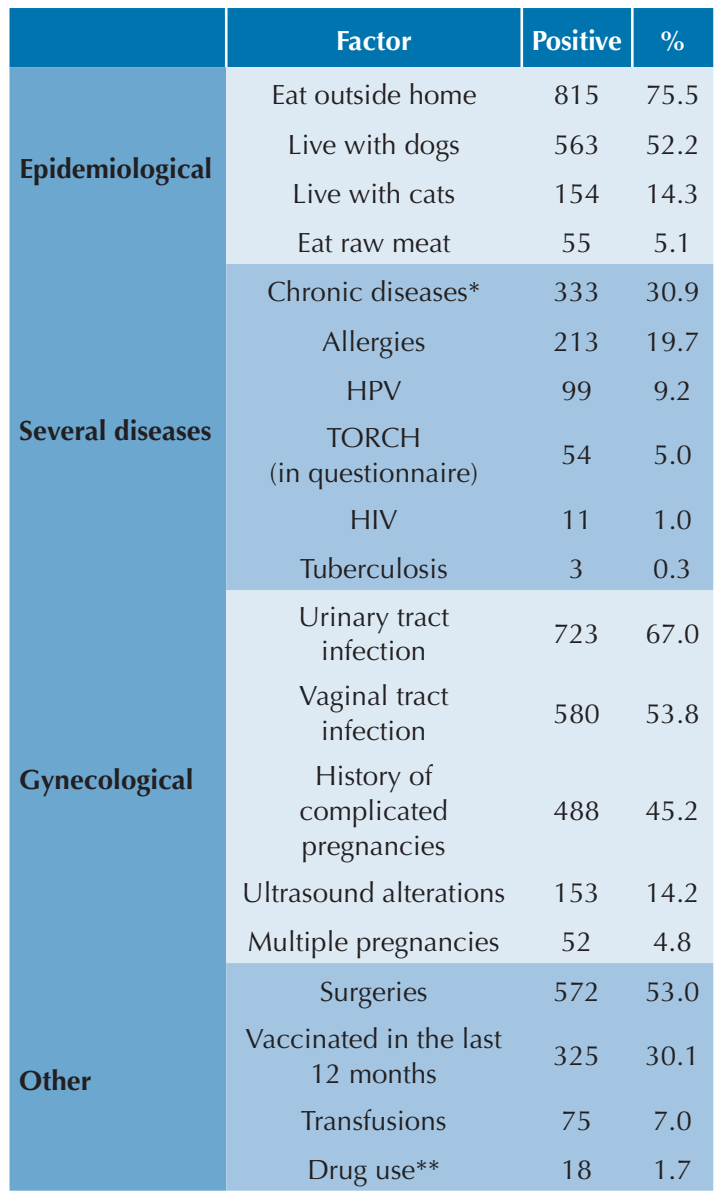

* From 333 non-infectious: hypothyroidism 65 (19.5\%), hypertension $40(12.0 \%)$, hypersensitivity $37(11.1 \%)$, diabetes $30(9.0 \%)$, heart disease $28(8.4 \%)$, autoimmunity 26 $(7.8 \%)$, hyperthyroidism $24(7.2 \%)$, renal $12(3.6 \%)$, other 105 (31.5\%). ** None intravenous infections studied are shown in Table 3 . In the bivariate analysis, we found a strong association of markers studied to fetal malformations of the actual pregnancy, and history of transfusions $(p<0.015)$. Infection by T. gondii was also associated with the last two variables, as well as with the consumption of raw meat, positive TORCH and infection with HPV $(p<0.04)$. Infection with parvovirus B19 was associated with stillbirths, while T. pallidum was associated with HIV $(p=0.022)$.

\section{DISCUSSION}

Mother-to-child-transmitted infections have been neglected, particularly in regions that are constrained socio-economically, where subnotification is frequent. ${ }^{3}$ Thus, there are few reports on the burden caused by these pathogens and less about all simultaneously, such as the present work. For this reason, we decided to study several TORCH-related markers and other perinatal infections in a group of pregnant women, who were admitted to a tertiary care hospital that specializes in pregnancy complications. In the univariate analysis, we observed that the participants had pets, reported eating in the street frequently and had chronic diseases. These factors are expected to be high in urban populations. We anticipated a high prevalence of these infections since they are known to cause obstetric problems. HPV was frequent among enrolled women of the Ciudad de México and Estado de Mexico zone, probably because they had not yet received the vaccine, whose program had started shortly before and only in specific populations. Nevertheless, chronic, non-infectious diseases were by far the primary concern in this group. The age distribution showed a large proportion of young women, likely because they are already considered a high-risk group in gynecology. We expected a larger frequency of risk markers in this group, but no association of any infection was found with age; in fact, there was a larger proportion of infections in the oldest group. 
Caballero-Ortega $\mathrm{H}$, et al. Congenital infections in pregnant women of Mexico

We detected anti-T. gondii IgG antibodies of low avidity in $17 / 830$ (2.0\%) screened women. Taking a transmission rate of around $20 \%$ for the second trimester of gestation, according to Dunn et al, the proportion of congenital toxoplasmosis would be four cases /1000 newborns. ${ }^{19}$ This is congruent with our findings from an open population postnatal screening pilot study in

Table 2. Frequency of infectious diseases among 1079 pregnant women from a tertiary care hospital in relation to age

\begin{tabular}{|c|c|c|c|c|c|c|c|c|c|c|}
\hline \multirow[b]{2}{*}{ Age } & \multirow[b]{2}{*}{$\mathbf{n}$} & \multirow[b]{2}{*}{$\begin{array}{l}\mathrm{n} \text { for syphilis } \\
\text { and } T \text {. gondii }\end{array}$} & \multicolumn{8}{|c|}{ Number (percent) positive cases } \\
\hline & & & $\begin{array}{l}\text { CMV } \\
\text {-IgM- }\end{array}$ & $\begin{array}{l}\text { Hepatitis B } \\
\text {-antigen- }\end{array}$ & $\begin{array}{c}\text { Hepatitis C } \\
\text {-total } \\
\text { antibodies- }\end{array}$ & $\begin{array}{c}\text { Parvovirus } \\
\text {-IgM- }\end{array}$ & $\begin{array}{c}\text { Rubella } \\
\text {-IgM- }\end{array}$ & $\begin{array}{l}\text { Syphilis } \\
\text {-IgM- }\end{array}$ & $\begin{array}{c}\text { Acute } T \text {. } \\
\text { gondif } \\
\text { infection* }\end{array}$ & $\begin{array}{l}\text { Risky } \\
\text { infection }\end{array}$ \\
\hline$<21$ & 260 & 204 & $1(0.4)$ & 0 & $3(1.2)$ & $6(2.3)$ & 0 & 0 & $3(1.5)$ & $13(5.0)$ \\
\hline $21-25$ & 198 & 167 & $1(0.5)$ & 0 & $2(1.0)$ & $4(2.0)$ & $1(0.5)$ & 0 & $1(0.6)$ & $9(4.5)$ \\
\hline $26-30$ & 203 & 155 & 0 & 0 & $3(1.5)$ & $5(2.5)$ & 0 & $1(0.6)$ & $4(2.6)$ & $13(8.4)$ \\
\hline $31-35$ & 184 & 134 & $1(0.5)$ & 0 & $4(2.2)$ & $1(0.5)$ & 0 & 0 & $4(3.0)$ & $10(7.5)$ \\
\hline$>35$ & 234 & 170 & $1(0.4)$ & 0 & $3(1.3)$ & $6(2.6)$ & 0 & $1(0.4)$ & $5(3.0)$ & $16(9.4)$ \\
\hline Total & 1079 & 830 & $4(0.4)$ & 0 & $15(1.4)$ & $22(2.0)$ & $1(0.1)$ & $2(0.2)$ & $17(2.0)$ & $61(5.7)$ \\
\hline
\end{tabular}

*Acute T. gondii infection of risk was considered only when low IgG avidity antibodies was demonstrated.

Table 3. Association of variables inquired and risk markers among 1079 pregnant women from a tertiary care hospital

\begin{tabular}{|c|c|c|c|c|c|c|c|}
\hline Variable & & $\mathbf{n}$ & (+) Risky infection & $\%$ & OR & $\mathrm{Cl} 95 \%$ & $\mathbf{p}$ \\
\hline \multirow{2}{*}{ Fetal malformation } & yes & 5 & 2 & 40.0 & \multirow{2}{*}{24.0} & \multirow{2}{*}{$3.1-185.8$} & \multirow{2}{*}{0.012} \\
\hline & no & 148 & 4 & 2.7 & & & \\
\hline \multirow{2}{*}{ Transfusions } & yes & 75 & 9 & 12.0 & \multirow{2}{*}{2.7} & \multirow{2}{*}{$1.3-5.8$} & \multirow{2}{*}{0.014} \\
\hline & no & 1004 & 48 & 4.8 & & & \\
\hline \multicolumn{8}{|c|}{ (+) T. gondii infection } \\
\hline \multirow{2}{*}{$\mathrm{TORCH}$} & yes & 4 & 43 & 9.3 & \multirow{2}{*}{6.1} & \multirow{2}{*}{ 1.9-19.6 } & \multirow{2}{*}{0.009} \\
\hline & no & 13 & 787 & 1.7 & & & \\
\hline \multirow{2}{*}{ Eating raw meat } & yes & 3 & 38 & 1.8 & \multirow{2}{*}{4.8} & \multirow{2}{*}{$1.3-17.3$} & \multirow{2}{*}{0.039} \\
\hline & no & 14 & 792 & 7.9 & & & \\
\hline \multirow{2}{*}{ HPV } & yes & 5 & 75 & 6.7 & \multirow{2}{*}{4.4} & \multirow{2}{*}{$1.5-12.9$} & \multirow{2}{*}{0.014} \\
\hline & no & 12 & 755 & 1.6 & & & \\
\hline \multirow{2}{*}{ Transfusions } & yes & 4 & 60 & 6.7 & \multirow{2}{*}{4.2} & \multirow{2}{*}{$1.3-13.2$} & \multirow{2}{*}{0.029} \\
\hline & no & 13 & 770 & 1.7 & & & \\
\hline \multirow{2}{*}{ Fetal malformation } & yes & 5 & 2 & 40.0 & \multirow{2}{*}{-} & \multirow{2}{*}{ - } & \multirow{2}{*}{0.001} \\
\hline & no & 114 & 0 & 0.0 & & & \\
\hline \multicolumn{8}{|c|}{ (+) Parvovirus B19 infection } \\
\hline \multirow{2}{*}{ History of stillbirths } & yes & 3 & 49 & 6.1 & \multirow{2}{*}{5.7} & \multirow{2}{*}{$1.3-24.5$} & \multirow{2}{*}{0.037} \\
\hline & no & 5 & 439 & 1.1 & & & \\
\hline & & & yphilis infection & & & & \\
\hline HIV & yes & 1 & 9 & 11.1 & 1027 & 5017810 & ערטת רט \\
\hline HIV & no & 1 & 819 & 1.0 & 102.3 & $3.9-1 / 81.0$ & 0.022 \\
\hline
\end{tabular}


which we confirmed two congenital cases out of $1,000$ newborns ( IC95\% $=0.2-7.2) \cdot{ }^{20}$ Certainly, toxoplasmosis deserves attention throughout the entire country, particularly in groups at risk, because it has been neglected. The association of this marker with the ingestion of raw meat, a main risk factor in tempered urban zones, supports the validity of this result. ${ }^{21}$ Although there are no reports on clinical toxoplasmosis due to transfusion, this route of transmission deserves further investigation, since it could cause subclinical infection, because we and others have found parasite DNA in the blood of $\sim 50 \%$ of asymptomatic infected adults, including pregnant women. ${ }^{22}$ Association between acute toxoplasmosis and HPV is difficult to explain, except that both were common, together with parvovirus B19. This might reflect poor hygienic and living conditions because the women treated at INPer are of a low socioeconomic level. The association between $T$. gondii and congenital malformations was also expected, since this parasite during the first stages of gestation, can cause alterations in the organogenesis of the fetus; in fact, we reported a case of anophthalmia and craniofacial cleft in an infection acquired during the first trimester of gestation, who arrived at INP as a clinical case. ${ }^{19,23}$

The second agent that deserves close attention because is not officially notified is parvovirus B19; the acute infection in pregnant women has been documented in several countries, such as Belgium $(0.15 \%)$, Finland (0.54\%), England \& Wales $(0.26 \%)$, Italy $(0.37 \%)$, Poland $(0.58 \%)$ and Nigeria (13.2\%). ${ }^{24,25}$ In Mexico, reports of cases in the general population and among medical staff indicate a frequency ranging from 3.1 to $29.2 \% .{ }^{26,27}$ Thus, the results obtained herein are relatively low, particularly considering that these women are a high-risk group. To the best of our knowledge, there have been no reports of congenital or prenatal parvovirus B19 infection in Mexico; therefore, the datum presented herein is the first and provides comparative data for other regions of the world. It must be emphasized that we searched IgM antibodies, which could also explain the low proportion found. Nevertheless, if it is vertically transmitted at a similar rate as T. gondii, it would be causing other 5 cases of congenital infection among 1000 newborns in the region studied. ${ }^{28}$ This statement would be congruent with the association found between parvovirus B19 and stillbirth. Table 3

The seroprevalence of HCV in pregnant women has been estimated to be around $1.0 \%(0.1 \%$ $2.4 \%$ ) worldwide. In Mexico, we did not find a previous study assessing the HCV seroprevalence in pregnant women; therefore, this study is the first, and the result $(1.4 \%)$ was within the global range. ${ }^{29,30}$ Since $70 \%$ of women with anti-HCV antibodies are expected to have viremia, and $4.3 \%$ of them transfer the infection to their babies, we expect that approximately 4 per 10,000 newborns would acquire the infection. ${ }^{30} \mathrm{Com}$ pared to CMV and T. gondii, an HCV congenital infection would be much less frequent, although specific studies must be conducted before any conclusions are made, since official reports about its incidence in women suggest that it is more frequent than rubella, HBV, syphilis and HIV.

Cytomegalovirus is the most frequent infectious agent of the TORCH infections worldwide. In developing countries, 50 to $90 \%$ of child-bearing age women are seropositive for IgG antibodies. ${ }^{2}$ In these regions, CMV is often acquired early in life due to higher proportions of breast-feeding and other risk factors. Vertical transmission frequency and severity in the newborn is much greater for primary maternal infection; however, non-primary infection is the most common. ${ }^{4}$ CMV affects nearly $0.7 \%$ of living newborns and is the leading cause of neurological problems of infectious origin at birth. ${ }^{31}$ In Mexico, Noyola et al reported that $0.89 \%$ of newborns were infected in a cross-sectional study. ${ }^{9}$ Despite its high frequency, CMV screening has not been imple- 
mented pre- or neonatally. ${ }^{4}$ New information suggests that valaciclovir treatment of pregnant women will soon allow the implementation of control programs for the congenital form. ${ }^{4,6}$ Our results are somewhat surprising since we found half the expected proportion in newborns; in this regard, no IgM cases were documented by Alvarado-Esquivel et al among 343 pregnant women of Durango. ${ }^{13}$

In this study, we found two positive cases for syphilis among 830 women, which is a lower proportion than that reported worldwide in 2013 $(<0.5 \%)$ but within the range of different cities of Mexico (0.26-2.3\%). ${ }^{32,33}$ This could also be due to testing IgM antibodies only, which are more closely related to active disease. Syphilis also remains an important cause of severe psychomotor disability and death in infants, particularly in resource-poor settings. Primary prevention, including antenatal care of pregnant women, is fundamental for congenital syphilis control and eventual eradication, which is cost-effective due to low price of treatment. ${ }^{34}$

Interestingly, only one positive case of rubella and no women with HBV were detected; both infections are under active universal vaccinationcontrol in Mexico. ${ }^{35}$ In 1993, Mexico joined the Pan American Health Organization initiative to eradicate measles from America, and rubella was integrated because of the similarity of symptoms. Actions such as epidemiological alerts, virologic surveillance and intensification of preventive immunoprophylaxis were included. ${ }^{36}$ As a result, few cases of congenital rubella infection have been officially reported since 2008, although there are sporadic reports due to active surveillance. ${ }^{14,37}$ Our results further support the success of this program in our country and are consistent with those reported by Alvarado-Esquivel et al in Durango, Mexico. ${ }^{14}$ The case reported here gave birth to an apparently healthy baby without evidence of congenital infection. This could be due to specificity problems of the diagnostic kit or to partial defense against fetal infection by the vaccination program, i.e., the challenge viral burden of the mother would be low thanks to vaccine-mediated herd immunity; the mother denied receiving the vaccine. The HBV incidence peaked in 2003 after the initiation of a risk-group focused vaccination program; however, this incidence has decreased since then, although it has not disappeared among women of Mexico City-Estado de Mexico. ${ }^{38}$ In this regard, our findings could be indicative of an important decay in recently acquired HBV. The co-infections found here could have a strong effect on pregnancy. Nevertheless, these women had no special obstetric problems, and their babies were born without clinical manifestations of congenital infection.

\section{CONCLUSIONS}

The main contribution of this work is the estimation of the relative burden of infections of potential risk to newborns. The main limitations of the study were the population type (women attended at a third level hospital) and the sample size, especially for rubella and HBV, which frequencies were 0.1 and zero, respectively; thus, we are not sure if they are present, although if so, they must be at very low levels. In conclusion, this type of cross-sectional studies could be useful to monitor disease burden and control programs effects. Remarkably, to our best knowledge, this is the only work that included seven infections (three which are not officially notified, i.e. T. gondii, parvovirus B19 and CMV) with potential for vertical transmission.

Acknowledgements. This work was partially financed by CONACYT grant 69666. Biomerieux_México provided $50 \%$ of the diagnostic kits of their trademark used in this study. 


\section{REFERENCES}

1. Correa D, Figueroa-Damián R. Infecciones congénitas y perinatales. Una visión integral. 1st ed. Ciudad de México: Médica Panamericana, 2014.

2. Neu N, Duchon J, Zachariah P. TORCH infections. Clin Perinatol 2015; 42 (1): 77-103. https://doi.org/10.1016/j. clp.2014.11.001.

3. Madrid L, Varo R, Sitoe A, Bassat Q. Congenital and perinatally-acquired infections in resource-constrained settings. Expert Rev Anti Infect Ther 2016; 14 (9): 845-61. https:// doi.org/10.1080/14787210.2016.1215913.

4. Leruez-Ville $M$, Ville Y. Fetal cytomegalovirus infection. Best Pract Res Clin Obstet Gynaecol 2017; 38: 97-107. https:// doi.org/10.1016/j.bpobgyn.2016.10.005.

5. Hahn HS, Kee MK, Kim HJ, Kim MY, Kang YS, Park JS, et al. Distribution of maternal and infant human papillomavirus: risk factors associated with vertical transmission. Eur J Obstet Gynecol Reprod Biol 2013; 169 (2): 202-6. https:// doi.org/10.1016/j.ejogrb.2013.02.024.

6. Ville $Y$, Leruez-Ville M. Managing infections in pregnancy. Curr Opin Infect Dis 2014; 27 (3): 251-7. doi: 10.1097/ QCO.0000000000000066.

7. Grant GB, Reef SE, Dabbagh A, Gacic-Dobo M, Strebel PM. Global progress toward rubella and congenital rubella syndrome control and elimination - 2000-2014. MMWR Morb Mortal Wkly Rep 2015; 64 (37): 1052-5. doi: 10.15585/ mmwr.mm6437a5.

8. Shih C, Chou SF, Yang CC, Huang JY, Choijilsuren G, Jhou RS. Control and eradication strategies of hepatitis $B$ virus. Trends Microbiol 2016; 24 (9): 739-49. doi: 10.1016/j. tim.2016.05.006

9. Noyola DE, Mejía-Elizondo AR, Canseco-Lima JM, AllendeCarrera R, Hernández-Salinas AE, Ramírez-Zacarías JL. Congenital cytomegalovirus infection in San Luis Potosí, Mexico. Pediatr Infect Dis J. 2003; 22 (1): 89-90. doi: 10.1097/00006454-200301000-00022.

10. Noyola DE, Malacara-Alfaro O, Lima-Rogel V, Torres-Montes A. Seroprevalence of syphilis in pregnant women in San Luis Potosí. Salud Publica Mex. 2006; 48 (2): 151-4. doi: 10.1590/s0036-36342006000200008.

11. Vázquez-Martínez JL, Coreño-Juárez MO, Montaño-Estrada LF, Attlan M, Gómez-Dantés H. Seroprevalence of hepatitis $B$ in pregnant women in Mexico. Salud Publica Mex 2003; 45 (3): 165-70. doi: 10.1590/s0036-36342003000300005.

12. Yañez-Alvarez I, Conde-González CJ, Uribe-Salas FJ, Olamendi-Portugal ML, García-Cisneros S, Sánchez-Alemán MA. Maternal/child seroprevalence of antibodies against Treponema pallidum at four general hospitals in the state of Morelos, Mexico. Arch Med Res 2012; 43 (7): 571-7. doi: 10.1016/j.arcmed.2012.10.001.

13. Alvarado-Esquivel $C$, Hernández-Tinoco J, SánchezAnguiano LF, Ramos-Nevárez A, Cerrillo-Soto SM, EstradaMartínez $S$, et al. Seroepidemiology of cytomegalovirus infection in pregnant women in Durango City, Mexico. BMC Infect Dis 2014; 14: 484. doi: 10.1186/1471-2334-14-484.

14. Alvarado-Esquivel C, Hernandez-Tinoco J, Sanchez-Anguiano LF, Ramos-Nevarez A, Cerrillo-Soto SM, Salas-Pacheco $J M$, et al. Rubella immune status in pregnant women in a Northern Mexican City. J Clin Med Res 2016a; 8 (9): 656-61. doi: $10.14740 /$ jocmr2635w.

15. Alvarado-Esquivel $C$, Terrones-Saldívar MC, HernándezTinoco J, Muñoz-Terrones MD, Gallegos-González RO, Sánchez-Anguiano LF, et al. Seroepidemiology of Toxoplasma gondii in pregnant women in Aguascalientes City, Mexico: a cross-sectional study. BMJ Open 2016b; 6 (7): e012409. doi: 10.1136/bmjopen-2016-012409.

16. Best JM, Reef $S$. The immunological basis for immunization series: module 11: rubella. In: World Health Organization, editor. Immunization, Vaccines and Biologicals. Switzerland: World Health Organization, 2008; 1-37.

17. Henao-Martínez AF, Johnson SC. Diagnostic tests for syphilis: New tests and new algorithms. Neurol Clin Pract 2014; 4 (2): 114-22. doi: 10.1212/01.CPJ.0000435752.17621.48.

18. Cañedo-Solares I, Ortiz-Alegría LB, Figueroa-Damián R, Bustos-Bahena ML, González-Henkel H, Calderón-Segura $\mathrm{E}$, et al. Toxoplasmosis in pregnancy: determination of IgM, IgG and avidity in filter paper-embedded blood. J Perinatol 2009; 29 (10): 668-72. doi: 10.1038/jp.2009.79.

19. Dunn D, Wallon M, Peyron F, Petersen E, Peckham C, Gilbert R. Mother-to-child transmission of toxoplasmosis: risk estimates for clinical counselling. Lancet 1999; 353 (9167): 1829-33. doi: 10.1016/\$0140-6736(98)08220-8.

20. Vela-Amieva M, Cañedo-Solares I, Gutiérrez-Castrellón $\mathrm{P}$, Pérez-Andrade $\mathrm{M}$, González-Contreras C, Ortíz-Cortés $J$, et al. Short report: neonatal screening pilot study of Toxoplasma gondii congenital infection in Mexico. Am J Trop Med Hyg 2005; 72 (2): 142-4. https://doi.org/10.4269/ ajtmh.2005.72.142.

21. Petersen E, Vesco G, Villari S, Buffolano W. What do we know about risk factors for infection in humans with Toxoplasma gondii and how can we prevent infections? Zoonoses Public Health 2010;57(1):8-17. doi: 10.1111/j.1863 2378.2009.01278.x.

22. Rico-Torres $C P$, Valenzuela-Moreno LF, Luna-Pastén $H$, Figueroa-Damián R, Gómez-Toscano V, Hernández-Delgado $L$, et al. High heterogeneity, mixed infections and new genotypes in human congenital toxoplasmosis cases in the mega-metropolis of Central Mexico. Acta Trop 2018; 178: 124-9. doi: 10.1016/j.actatropica.2017.11.008.

23. Arce-Estrada GE, Gómez-Toscano V, Cedillo-Peláez C, Sesman-Bernal AL, Bosch-Canto V, Mayorga-Butrón JL, et al. Report of an unusual case of anophthalmia and craniofacial cleft in a newborn with Toxoplasma gondii congenital infection. BMC Infect Dis 2017; 17 (1): 459-63. doi: 10.1186/s12879-017-2565-8.

24. Mossong J, Hens N, Friederichs V, Davidkin I, Broman M, Litwinska B, et al. Parvovirus B19 infection in five European countries: seroepidemiology, force of infection and 
Caballero-Ortega $\mathrm{H}$, et al. Congenital infections in pregnant women of Mexico

maternal risk of infection. Epidemiol Infect 2008; 136 (8): 1059-68. doi: 10.1017/\$0950268807009661.

25. Emiasegen SE, Nimzing L, Adoga MP, Ohagenyi AY, Lekan R. Parvovirus B19 antibodies and correlates of infection in pregnant women attending an antenatal clinic in central Nigeria. Mem Inst Oswaldo Cruz 2011; 106 (2): 227-31. doi: 10.1590/s0074-02762011000200018.

26. Barriga-Angulo G, Castillo-Torres NP, Tapia-Jamett H. La infección por Parvovirus B19 en México. Rev Mex Patol Clín 1995; 42 (4): 160-3.

27. Mancebo-Hernández A, González-Rivera A, GonzálezSaldaña N, Lombardo-Aburto E. Estudio de un brote de infección por Parvovirus B19 en un hospital de la Ciudad de México. Acta Ped Mex 2006; 27 (2): 66-72.

28. Crane J, Mundle W, Boucoiran I, Maternal Fetal Medicine Committee. Parvovirus B19 infection in pregnancy. J Obstet Gynaecol Can 2014; 36 (12): 1107-16. doi: 10.1016/S17012163(15)30390-X.

29. Indolfi G, Resti M. Perinatal transmission of hepatitis $C$ virus infection. J Med Virol. 2009; 81 (5): 836-43. doi. 10.1002/jmv.21437.

30. Wen JW, Haber BA. Maternal-fetal transmission of hepatitis C infection: what is so special about babies? J Pediatr Gastroenterol Nutr 2014; 58 (3): 278-82. doi: 10.1097/ MPG.0000000000000258.

31. Joseph A, Mahida N, Irving W, Soo S. Congenital cytomegalovirus infection. Paed Child Health 2014; 24: 255-9.

32. Newman L, Kamb M, Hawkes S, Gomez G, Say L, Seuc A, et al. Global estimates of syphilis in pregnancy and associated adverse outcomes: analysis of multinational antenatal surveillance data. PLoS Med. 2013;10: e1001396. https:// doi.org/10.1371/journal.pmed.1001396.

33. Sánchez-Alemán MA, Conde-González CJ. Sífilis congénita. In: Correa D, Figueroa R, editors. Infecciones Congénitas y Perinatales. Una visión integral. Ciudad de México: Médica Panamericana, 2014; 115-22.

34. Meredith S, Hawkes S, Schmid G, Broutet N. The global elimination of congenital syphilis: rationale and strategy for action. Geneva: WHO Library Cataloguing-in-Publication Data, 2007.

35. Santos JI. Vaccination in Mexico in the context of the "vaccine decades": achievements and challenges. Gac Med Mex. 2014; 150: 180-8.

36. Díaz-Ortega JL, Meneses-Reyes CD, Palacios-Martínez M. Incidence and transmission patterns of rubella in Mexico. Salud Publica Mex. 2007;49:337-44. doi: 10.1590/s003636342007000500004.

37. Metcalf CJ, Bjørnstad ON, Ferrari MJ, Klepac P, Bharti N, Lopez-Gatell H. Grenfell BT. The epidemiology of rubella in Mexico: seasonality, stochasticity and regional variation. Epidemiol Infect 2011; 139: 1029-38. https:// doi.org/10.1017/S0950268810002165[Opens in a new window].

38. Boletín epidemiológico. Sistema Nacional de Vigilancia Epidemiológica. Sistema Único de Información. Dirección General de Epidemiología, 2019. https://www.gob.mx/ salud/acciones-y-programas/direccion-general-de-epidemiologia-boletin-epidemiologico. 